\title{
Öğretmen Adaylarının Eğitim Programı Okuryazarlığı Düzeyleri*
}

\author{
Prospective Teachers' Levels of Curriculum Literacy \\ Dr. Cahit ERDEM ${ }^{1}$, Dr. Öğr. Üyesi Eray EĞMIR²
}

\begin{abstract}
Özet
$\mathrm{Bu}$ araştırmada, öğretmen adaylarının eğitim programı okuryazarlı̆̆ düzeylerini belirlemek ve bu düzeylerin cinsiyet, yaş, öğrenim türü, bölüm ve akademik başarı gibi değişkenlere göre farklılaşma durumunu incelemek amaçlanmaktadır. Betimsel bir saha taraması olarak desenlenen bu çalışmada veriler Bolat (2017) tarafindan geliştirilen 'Eğitim Programı Okuryazarlığı Ölçeği' aracıllı̆ııla öğretmen adaylarından toplanmıştır. Çalışmanın katılımcıları bir devlet üniversitesinin eğitim fakültesinde öğrenim gören dördüncü sınıf öğretmen adayları ile aynı fakültede pedagojik formasyon eğitimi alan toplamda 210 öğretmen adayından oluşmaktadır. Araştırmada veriler betimsel istatistikler, bağımsız örneklem $t$ testi ve tek yönlü varyans analizi yöntemleri ile analiz edilmiştir. Araştırmada ortaya çıkan temel bulgular şöyledir: öğretmen adaylarının eğitim programı okuryazarlığı düzeyi ölçek toplamında 3,72 (oldukça katıllyorum) olarak belirlenmiştir; öğretmen adayları 'okuma' boyutunda 'yazma' boyutuna göre daha başarılıdır; öğretmen adaylarının eğitim programı okuryazarlığı düzeyleri ölçek toplamında cinsiyet, yaş ve öğrenim türü değişkenlerine göre anlamlı düzeyde farklılaşmazken bölüm ve akademik başarı değişkenlerine göre farklılaşmaktadır. Araştırma sonuçlarının öğretmen adaylarının eğitim programı okuryazarlığı düzeylerini ortaya koymanın yanı sıra alanda yeni bir kavram olan eğitim programı okuryazarlı̆̆ını ön plana çıkarması önemli görülmektedir.
\end{abstract}

Anahtar Kelimeler: Okuryazarlık, eğitim programı okuryazarlı̆̆ı, öğretmen adayları

\begin{abstract}
This study aims to identify prospective teachers' levels of curriculum literacy and examine how these levels differ by variables of gender, age, type of education, department and academic achievement. In this descriptive survey model study, the data were gathered from prospective teachers through 'Curriculum Literacy Scale', developed by Bolat (2017). The participants are 210 prospective teachers at fourth grade at the education faculty of a state university and prospective teachers registered in the pedagogic formation program of the same faculty. The data were analyzed through descriptive statistics, independent samples t test and one-way variance analysis methods. The key findings of the study include: the prospective teachers' level of curriculum literacy is 3,72 (quite agree) in the total scale; the prospective teachers are more successful in 'reading' factor than 'writing' factor; the prospective teachers' level of curriculum literacy differs significantly by department and academic achievement but does not differ significantly by gender, age and type of education in the total scale. As well as putting forth prospective teachers' levels of curriculum literacy, the study is also significant as it features curriculum literacy, which is a new concept in the field.
\end{abstract}

Keywords: Literacy, curriculum literacy, prospective teachers

\footnotetext{
* Bu çalışmanın ilk hali, 9-11 Mayıs 2018 tarihlerinde Manisa'da düzenlenen VIII. Uluslararası Eğitimde Araştırmalar Kongresi'nde sözlü bildiri olarak sunulmuştur.

${ }^{1}$ Afyon Kocatepe Üniversitesi, Yabancı Diller Yüksekokulu, cerdem@ aku.edu.tr , Orcid ID: orcid.org/0000-0001-6988-8122

${ }^{2}$ Afyon Kocatepe Üniversitesi, Eğitim Fakültesi, eegmir@ aku.edu.tr, Orcid ID: orcid.org/0000-0003-3054-1011
} 


\section{Giriş}

Geniş çeşitlilikte sosyal ve kültürel eylemler içeren okuryazarlık kavramına (Lankshear ve Knobel, 2008) yüklenen anlamlar zaman içerisinde sürekli olarak değişmiştir. Artık okuryazarlık yazılı metinleri okuyup yeni metinler üretebilmek ile sınırlandırılmamakta; özel bir alanda bilgi sahibi olmaya işaret etmektedir (Som ve Kurt, 2012). Okuryazarlık bu özel alanlarda gerekli olan beceri ve yeterliklere sahip olmay1 içermekle beraber (Erişti ve Erdem, 2017) bununla sınırlı değildir; okuryazarlığ 1 sosyal, teknolojik ve ekonomik faktörlerden bağımsız düşünmek mümkün olamaz (Kress, 2003). Sosyal ve kültürel değişimlere göre değişen ve gelişen okuryazarlık belirli türdeki metinleri ve eserleri okumak, yorumlamak ve üretmek için bilgi ve becerileri edinmeyi ve bireyin kültürüne ve toplumuna tam anlamıyla katılması için kapasitelerini geliştirmeyi içerir (Kellner ve Share, 2005). Street (2003, s.79) ise okuryazarlığ 'kültürel bağlamlarda düşünme ve okuma-yazma yolları' olarak tanımlamıştır.

Okuryazarlığa yüklenen anlamlar zaman içinde değişse de tarihsel süreçte yapılan okuryazarlık tanımlarının üç ortak noktası olduğu ileri sürülebilir: a) okuma ve yazmanın kendine özgü yönlerine ilişkin beceri, b) toplumun genel talepleri çerçevesinde bağlamsallaştırma, c) belirli bir düzeyde kullanılabilir yeterlilik (Cunningham, 2000). Aynı zamanda, okuryazarlık kavramı "yeterlik" veya "beceri" kavramları ile aynı anlamda kullanılma eğilimindedir (Goodfellow, 2011). Ancak okuryazarlık çeşitli ortamlardaki iletişim ile ilişkili olduğu için okuryazarlık yerine önerilen yeterlik, insan kaynağı, bilişsel beceri vb. terimler yeterli olmamıştır; çünkü bu terimler iletişime aracılık eden metinsellik ve teknolojiyi yok saymaktadırlar (Livingstone, 2003). Bu nedenle özellikle bilgi ve iletişim teknolojilerinin gelişimi ile medya okuryazarlığı (Erdem, 2018), dijital okuryazarlık (Bawden, 2001), ağ okuryazarlığı (Pegrum, 2010), sosyal medya okuryazarlı̆̆ (Livingstone, 2014) gibi farklı okuryazarlık türleri araştırmacıların gündemine girmiştir. Ancak okuryazarlık bakış açısı, bilgi ve iletişim teknolojileri ile ilgili alanlarla sınırlı değildir; bilgi okuryazarlığı (Kurbanoğlu, 2010), finans okuryazarlığı (Şahin ve Barış, 2017), matematik okuryazarlığı (OECD, 2006), hukuk okuryazarlığı (Yanılmaz, 2011) gibi diğer birçok alanda ilgili konuda bilgi sahibi olmaktan ziyade okuryazarlık anlayışı hâkim olmaya başlamıştır.

Konu eğitim bilimleri açısından ele alındığında ise, eğitim programı okuryazarlığı öğretmenlerin ve öğretmen adaylarının kazanması gereken önemli bir okuryazarlık türü olarak karşımıza çıkmaktadır. Eğitim programı okuryazarlı̆̆ 1 aynı zamanda program okuryazarlığı olarak da ifade edilmektedir. Bu okuryazarlık türü Keskin ve Korkmaz (2017) tarafından eğitim programları hakkında bilgi sahibi olma, onları yorumlayabilme, eleştirel bir gözle inceleyerek eğitim programlarını içinde bulunduğu şartlara uygun olarak uyarlayabilme olarak tanımlanmaktadır. Akınoğlu ve Doğan (2012) ise eğitim programlarının hayata geçirilebilmesinin en önemli koşulunun öğretmenlerin eğitim programlarının yapısı, kapsamı, ilişki ve özelliklerini anlaması ve programı hayata geçirmek için yapılması gerekenleri planlamasına bağlı olduğunu vurgulamışlardır. Eğitim programı uygulanırken öğretmenlerin içinde bulundukları okulun özelliklerini ve sinırlılıklarını bilmeleri, okulun önceliklerini ve öğrenci ve eğitimcilerin ihtiyaçlarını anlamaları gerekmektedir. $\mathrm{Bu}$ doğrultuda öğretmenin eğitim programı ile ilişkili olarak hedef ve amaçları, konu alanını, yöntem, materyal ve araçları, uygun öğrenme yaşantılarını seçme ve uygulaması ve bu süreci değerlendirmesi gerekmektedir (Ornstein ve Hunkins, 2017). Eğitim programı okuryazarlığı öğretmenin rutin planları uygulamak yerine var olan durumu 
yorumlayarak uygun ve uyarlanabilir bir planlama yapmasını mümkün kılar (Nsibande ve Modiba, 2012). Eğitim programı okuryazarı olan bir öğretmen kendisinden beklenen bu gereklilikleri yerine getirebilecektir.

Ornstein ve Hunkins (2017) program geliştiricilerin çoğunlukla teori ile pratiği birleştirmede sorun yaşadıklarına ve eğitim programlarının daha çok teori ağırlıklı olduğuna; buna karşın uygulayıcıların pratiğe daha çok önem verdiklerinden teorik boyutu yok saydıklarına işaret etmişlerdir. Bu durum amaçlanan eğitim programı ile uygulanan eğitim programı arasında önemli farklılıkların ortaya çıkmasına neden olabilmektedir. $\mathrm{Bu}$ bağlamda, eğitim programının uygulayıcısı olan öğretmenlerin eğitim programlarını doğru bir şekilde anlamaları büyük önem taşımaktadır.

Öğrenme sürecinde kilit öneme sahip olan eğitim programı kavramı tarihsel süreç içerisinde farklı şekillerde tanımlanmış ve kabul edilmiştir. Süreç içerisinde eğitim programı konular listesi, ders içerikleri, ders programları olarak görülmekten çıkmış okul içinde ve dışında yaşanan deneyimler, eğitsel bir rehber ya da ulaşılmak istenen çıktılar olarak görülmüştür. Demirel (2017, s.4) eğitim programını "öğrenene, okulda ve okul dışında planlanmış etkinlikler yoluyla sağlanan öğrenme yaşantıları düzeneği” olarak tanımlamaktadır. Oliva (2009) ise eğitim programını öğrencilerin okulun yönlendirmesi sürecinde karşılaştıkları öğrenme yaşantıları için bir plan olarak görür ve eğitim programının bu yaşantıları yönlendirmek ve sıralamak için bir araç işlevi gördüğünü ifade etmektedir. İster okulda öğretilen dersler olarak dar bir anlamda ister bireylerin topluma katılımı için ihtiyaç duyduğu deneyimler olarak geniş anlamda bakılsın, eğitim programlarının eğitimcileri, öğrencileri ve toplumun tüm kesimlerini etkilediği açıktır (Ornstein ve Hunkins, 2017).

Eğitim programı farklı şekillerde tanımlansa da eğitim programının temel ögeleri konusunda alanyazında bir fikir birliği olduğu söylenebilir. Eğitim programının temel ögeleri amaç, içerik, öğretme-öğrenme süreci ve ölçme ve değerlendirme olarak kabul edilmektedir. Bu ögeler Tyler'ın (1949) ortaya atmış olduğu, program geliştirme sürecinde cevaplanması gereken dört soruya karşılık gelmektedir. Bu sorular sırasıyla (1) Okul hangi eğitsel amaçları edindirmeye çalışmalıdır? (2) $\mathrm{Bu}$ amaçları edindirmek için hangi eğitsel yaşantılar sağlanmalıdır? (3) $\mathrm{Bu}$ eğitsel yaşantılar etkili bir şekilde nasıl düzenlenebilir ve uygulanabilir? (4) Bu amaçların edinilip edinilmediğini nasıl belirleyebiliriz? Bu ögelere ek olarak bağlam da eğitim programının temel ögeleri arasında kabul edilmeye başlanmıştır. Programın felsefi temelleri, program tasarım yaklaşımı ve modeli, program geliştirme modeli, programda yer alan öğrenme kuramları gibi hususlar bağlam ögesi içerinde değerlendirilebilir (Demirel, 2017).

Yukarıda ifade edilen ögelerle ilişkili olarak, Demeuse ve Strauven (2016) eğitim programının bileşenlerini şöyle sıralamışlardır: gerçekleştirilecek öğrenmeler, öğrenmeöğretme stratejileri ve uygulanacak süreçler, öğretim kaynakları veya hem öğrenciler hem de öğretmenlere sağlanan eğitsel kaynaklar ve bunların kullanımına ilişkin yönergeler, ders içerikleri, gerçekte beklenen sonuçlar ve öğrenmenin ne derece gerçekleştiğini kontrol etme amacına yönelik sınama koşulları, ve eğitim programlarının uygulanmasına (yönetimine) ilişkin düzenlemeler. 
Öğretmenlerin eğitim programından etkili bir şekilde faydalanabilmeleri için eğitim programının bileşenlerine hâkim olmaları gerekmektedir ve bunun için çeşitli yeterliklere ihtiyaç duyulmaktadır. Bolat (2017, s.129) bu yeterlikleri Tablo 1'deki gibi sıralamış ancak aynı zamanda bu yeterliklerin geliştirilebileceği ve artırılabileceğini de vurgulamıştır. Eğitim programı okuryazarlığı yeterlikleri olarak ifade edilen bu yeterlikler eğitim programının hedef, içerik, öğrenme öğretme süreci ve ölçme ve değerlendirme ögelerini kapsamaktadır. Eğitim programının bağlam boyutunun ise eksik kaldığı görülmektedir.

Tablo 1: Eğitim programı okuryazarlığı yeterlikleri

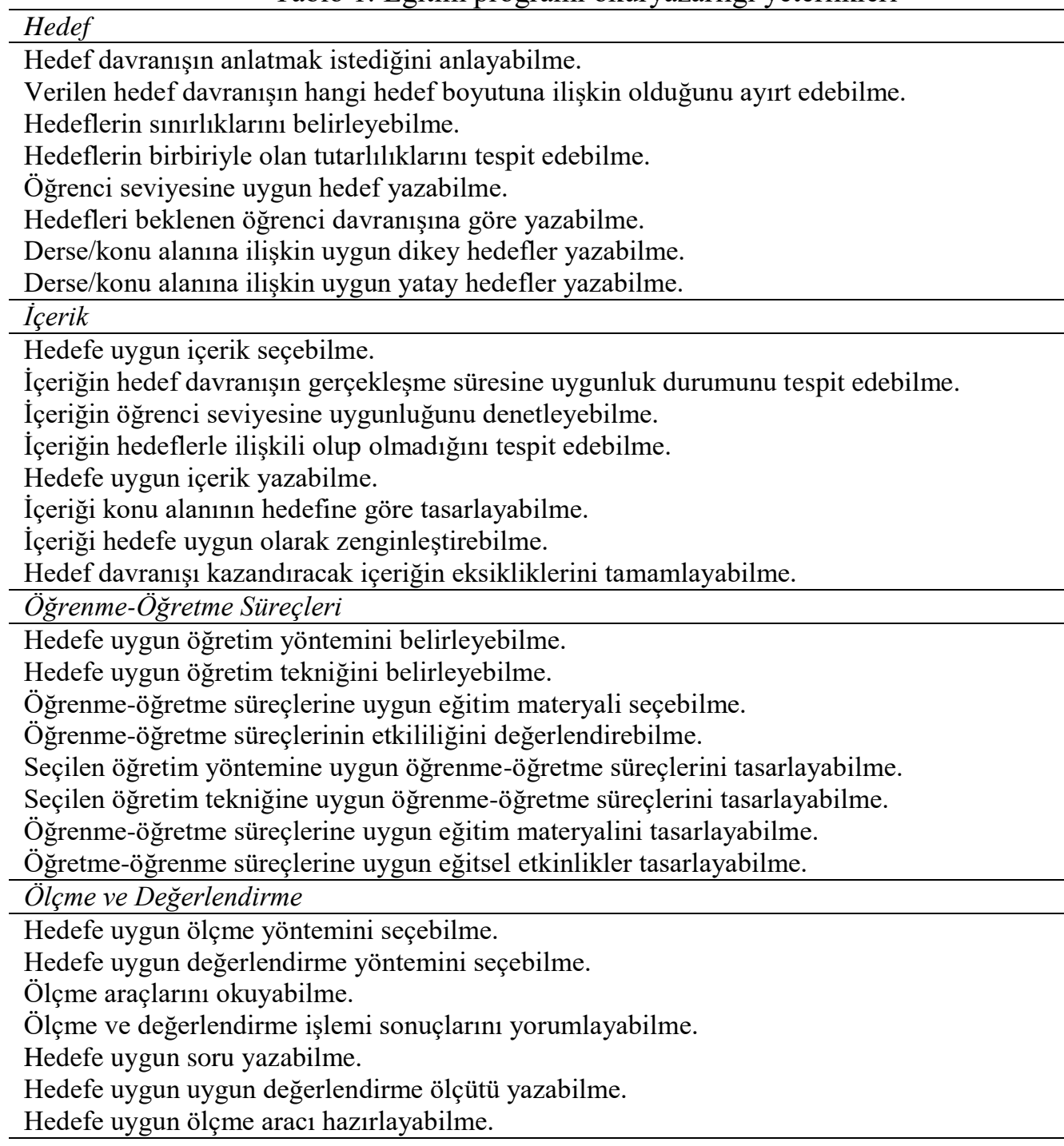

Eğitim programlarının geliştirilme ve uygulanma sürecinde öğretmenler merkezi bir role sahiptirler. Öğretmenler öğretim yoluyla eğitim programını hayata geçirirler. Kullanılan öğretim yöntem ve uygulamaları öğrencilerin eğitim programı deneyimlerini şekillendirecektir (Ornstein ve Hunkins, 2017). Tablo 1'de yer alan temel yeterliklere sahip olan bir öğretmenin eğitim programını en iyi şekilde hayata geçireceği ifade edilebilir. Bu noktada eğitim programlarının uygulayıcıları olan öğretmenlerin öğretim programını nasıl anladıkları, bu konudaki bilgi düzeyleri, programa karşı tutumları ve programı uygulamaya 
dönüştürebilme beceri ve yeterliklerinin ne düzeyde olduğu önemli sorun alanlarından biridir ve eğitim programı okuryazarlığı kavramı bu sorunu daha anlaşılabilir ve ölçülebilir hale getirmektedir (Akınoğlu ve Doğan, 2012).

Son yıllarda öğretmenlerin eğitim programı geliştirme çalışmalarında çok daha fazla sorumluluk almaya başlaması (Wiles, 2016) ve Türkiye'de son dönemlerde geliştirilen öğretim programlarına bakıldığında çerçeve program anlayışına doğru bir kayma olduğu gerçeği birlikte düşünüldüğünde öğretmenlere bu anlamda daha çok sorumluluk düştüğü görülmektedir. Öğretmenlerin eğitim programı okuryazarlığını kazandıkları temel kurum ise hizmet öncesi öğretmen yetiştirme programlarıdır. Bu programlarda öğretmen adayları eğitim programının kullanımına ilişkin teorik ve uygulamalı dersler almaktadır. Eğitim programı okuryazarlığı temel olarak hizmet öncesi öğretmen yetiştirme süreçlerinde öğretmen adaylarına kazandırılmalıdır (Bolat, 2017). Ancak bu eğitim sürecinin etkililiği, öğretmen adaylarının ne düzeyde eğitim programı okuryazarı olduğu gibi hususlar araştırmalarda yeterli düzeyde incelenmemiştir. Eğitim programı okuryazarlı̆̆ 1 kavramı ise bu sorun alanını kavramsallaştırdığı ve ölçülebilir hale getirdiği için önem taşımaktadır. $\mathrm{Bu}$ ihtiyaçtan hareketle, bu araştırmada ögretmen adaylarının eğitim programı okuryazarlığı düzeylerini belirlemek amaçlanmaktadır. Bu amaçla cevabı aranan sorular şunlardır:

1. Öğretmen adaylarının eğitim programı okuryazarlı̆̆ı düzeyleri nedir?

2. Öğretmen adaylarının eğitim programı okuryazarlığı düzeyleri cinsiyet değişkenine göre anlamlı farklılık göstermekte midir?

3. Öğretmen adaylarının eğitim programı okuryazarlığı düzeyleri öğrenim türü değişkenine göre anlamlı farklılık göstermekte midir?

4. Öğretmen adaylarının eğitim programı okuryazarlığı düzeyleri yaş değişkenine göre anlamlı farklılık göstermekte midir?

5. Öğretmen adaylarının eğitim programı okuryazarlığı düzeyleri bölüm değişkenine göre anlamlı farkl11ı göstermekte midir?

6. Öğretmen adaylarının eğitim programı okuryazarlığı düzeyleri akademik başarı değişkenine göre anlamlı farklılık göstermekte midir?

\section{Yöntem}

\subsection{Araştırma Deseni}

$\mathrm{Bu}$ araştırma betimsel bir saha taraması araştırmasıdır. Saha taraması araştırmaları bir evrende yer alan eğilimlerin, tutumların ya da görüşlerin nicel olarak belirlenmesi için o evreni temsil eden bir örneklemden veri toplamayı içerir (Creswell, 2014). Bu araştırmada öğretmen adaylarının kendi eğitim programı okuryazarlığı düzeylerine ilişkin görüşlerini belirlemek amaçlandığından betimsel tarama modeli tercih edilmiştir. Bu amaçla, bir devlet üniversitesinin eğitim fakültesinde öğretmenlik programlarında ve pedagojik formasyon programlarında öğrenim gören öğretmen adaylarından bir ölçek yardımıyla veriler toplanmış ve analiz edilmiştir.

\subsection{Katılımcılar}

$\mathrm{Bu}$ çalışmada veriler 2017-2018 akademik y1lı bahar döneminde bir devlet üniversitesinin eğitim fakültesinde öğrenim gören dördüncü sınıf öğrencileri ile pedagojik formasyon eğitimi alan öğrencileri arasından uygun örnekleme yöntemiyle belirlenmiş ve 
araştırmaya katılmaya gönüllük gösteren 210 öğretmen adayından toplanmıştır. Katılımcılara ilişkin bilgiler Tablo 2'de sunulmuştur.

Tablo 2: Katılımciların demografik bilgileri

\begin{tabular}{ccccccccc}
\hline & $\begin{array}{c}\text { Türkçe } \\
\text { Ö. }\end{array}$ & $\begin{array}{c}\text { Mat. } \\
\text { Ö. }\end{array}$ & $\begin{array}{c}\text { Sosyal } \\
\text { B.Ö. }\end{array}$ & $\begin{array}{c}\text { Bölüm } \\
\text { Tarih }\end{array}$ & Mat. & TDE & Biyoloji & Toplam \\
\cline { 2 - 7 } Öğretmenlik & 35 & 31 & 26 & - & - & - & - & 92 \\
Ĕgitimi & - & - & - & 31 & 28 & 39 & 20 & 118 \\
Formasyon & - & 31 & 26 & 31 & 28 & 39 & 20 & 210 \\
$\quad$ Toplam & 35 & & &
\end{tabular}

Tablo 2'de bölümlere göre dağılımı görüldüğü üzere 92 öğretmenlik eğitimi öğrencisi ve 118 pedagojik formasyon öğrencisinden; toplamda ise 210 öğretmen adayından veri toplanmıştır. Katılımcıların \%28'i erkek (59), \%72'si ise kadındır (151). Öğretmen adaylarının mezuniyet öncesi düzeylerinin belirlenmesi için öğretmenlik programında okuyan öğrencilerden sadece 4. sınıf öğrencileri örnekleme dahil edilmiş ve veriler bahar döneminin sonuna doğru toplanmıştır.

\subsection{Verilerin Toplanması ve Analizi}

Araştırmada veriler 2017/2018 akademik yılı bahar döneminde bir devlet üniversitesinin eğitim fakültesinde öğrenim gören öğretmenlik eğitimi programlarında ve pedagojik formasyon programlarında eğitim gören öğretmen adaylarından toplanmıştır. Veri toplama süreci başlamadan önce ilgili eğitim fakültesinden gerekli izinler alınmıştır. Veriler Bolat (2017) tarafından geliştirilen "Eğitim Programı Okuryazarlığı Ölçeği” aracılığı ile toplanmıştır. Ölçek sahibinden ölçeğin kullanım izni alınmıştır. "Okuma" (15) ve "yazma" (14) olarak iki faktörden oluşan ölçekte 29 madde yer almaktadır. Ölçekte yer alan maddeler 'Hiç katılmıyorum, az katılıyorum, orta düzeyde katılıyorum, oldukça katılıyorum ve tamamen katıllyorum' şeklinde beşli Likert olarak düzenlenmiştir. Ölçeğin Cronbach's Alpha iç tutarlılık katsayısı 0,94 'tür. Bu değer okuma faktörü için 0,88 , yazma faktörü için 0,91 'dir. Ölçek toplam varyansın \%43,54'ünü açıklamaktadır. Bu uygulamada ölçeğinin bütününün Cronbach's Alpha iç tutarlılık katsayısı 0,91; okuma faktörünün 0,88, yazma faktörünün ise 0,82 olarak belirlenmiştir. Bu düzeyler yüksek düzeyde güvenirliğe işaret etmektedir (Tavşancıl, 2006).

Verilerin analizi aşamasında ilk olarak verilerin normal dağılım gösterip göstermediği incelenmiştir. Bu amaçla gerçekleştirilen normal dağglım analizlerinde, Shapiro-Wilk testi anlamlılık değeri 0,440 olarak belirlenmiştir ( $>0,05$ ). Ayrıca çarpıklık değeri 0,055 , basıklık değeri ise 0,546 olarak belirlenmiştir. $\mathrm{Bu}$ değerler verilerin normal dağılım gösterdiğini ortaya koymuş ve parametrik testlerin uygun olduğuna karar verilmiştir. Öğretmen adaylarının eğitim programı okuryazarlığı düzeylerini belirlemek için betimsel istatistiklerden, eğitim programı okuryazarlığı düzeylerinin cinsiyet ve öğrenim türü değişkenlerine göre farklılaşma durumunu belirlemek için bağımsız örneklem t testinden; yaş, bölüm ve akademik başarı değişkenlerine göre farklılaşma durumunu belirlemek için tek yönlü varyans analizinden (ANOVA) faydalanılmıştır. 


\section{Bulgular}

\section{1. Öğretmen Adaylarının Eğitim Programı Okuryazarlığı Düzeyleri}

Birinci araştırma sorusu doğrultusunda, öğretmen adaylarının eğitim programı okuryazarlığı düzeyi ve faktörlerin ortalamalarına ilişkin betimsel istatistikler Tablo 3 'te sunulmuştur.

Tablo 3: Öğretmen adaylarının eğitim programı okuryazarlı̆̆ düzeyleri

\begin{tabular}{cccc}
\hline Boyutlar & $\mathrm{N}$ & $\overline{\mathrm{X}}$ & ss \\
\hline Okuma & 210 & 3,81 & 0,55 \\
Yazma & 210 & 3,63 & 0,62 \\
Toplam & 210 & 3,72 & 0,54 \\
\hline
\end{tabular}

Öğretmen adaylarının ölçeğin toplamından 3,72 ortalama puan aldıkları görülmektedir. Bu düzey 'oldukça katılıyorum' seçeneğine uygun düşmektedir. Boyutlar açısından bakıldığında, öğretmen adaylarının yazma boyutunda $(3,63)$ okuma boyutuna $(3,81)$ göre daha düşük ortalama puana sahip oldukları görülmektedir. Öğretmen adaylarının madde bazında almış oldukları ortalama puanlar ise Tablo 4'de sunulmuştur.

Tablo 4: Ölçek maddelerinin ortalama puanları

\begin{tabular}{lcc}
\hline Madde & $\bar{X}$ & ss \\
\hline 1.Verilen hedef davranışın hangi hedef boyutuna ilişkin olduğunu ayırt edebilirim. & 3,62 & 0,88 \\
2.İeriğin öğrenci seviyesine uygunluğunu denetleyebilirim. & 3,92 & 0,73 \\
3.Hedefe uygun içerik seçebilirim. & 3,95 & 0,86 \\
4.Hedeflerin birbiriyle olan tutarlılıklarını tespit edebilirim. & 3,92 & 0,81 \\
5.İeriğin hedeflerle ilişki düzeyini tespit edebilirim. & 3,77 & 0,76 \\
6.Ölçme araçlarını okuyabilirim. & 3,73 & 0,90 \\
7.Hedeflerin snnırlıklarını belirleyebilirim. & 3,65 & 0,87 \\
8.Hedef davranışın ne istediğini anlayabilirim. & 4,04 & 1,4 \\
9.Öğretme-öğretme süreçlerinin etkililiğini değerlendirebilirim. & 3,81 & 0,83 \\
10.Ölçme-değerlendirme işlemi sonuçlarını yorumlayabilirim. & 3,86 & 0,86 \\
11.Hedefe uygun değerlendirme yöntemini seçebilirim. & 3,77 & 0,77 \\
12.Hedefe uygun öğretim tekniğini belirleyebilirim. & 3,81 & 0,84 \\
13.Öğrenme-öğretme süreçlerine uygun eğitim materyali seçebilirim. & 3,80 & 0,90 \\
14.İçeriğin hedef davranışın gerçekleşme süresine uygunluk durumunu tespit edebilirim. & 3,60 & 0,82 \\
15.Hedefe uygun öğretim yöntemini belirleyebilirim. & 3,77 & 0,90 \\
16.Öğrenme-öğretme süreçlerine uygun eğitim materyalini tasarlayabilirim. & 3,54 & 0,94 \\
17.Hedefe uygun ölçme aracı hazırlayabilirim. & 3,52 & 0,91 \\
18.Öğretme-öğrenme süreçlerine uygun eğitsel etkinlikler tasarlayabilirim. & 3,64 & 0,88 \\
19.Hedefe uygun uygun değerlendirme ölçütü yazabilirim. & 3,44 & 0,86 \\
20.Hedefleri beklenen öğrenci davranışına göre yazabilirim. & 3,60 & 0,85 \\
21.Öğrenci seviyesine uygun hedef yazabilirim. & 3,74 & 0,87 \\
22.Bir ölçme aracını hedefleri dikkate alarak analiz edebilirim. & 3,62 & 0,85 \\
23.Hedefe uygun soru yazabilirim. & 3,91 & 0,84 \\
24.Seçtiğim öğretim tekniğine uygun öğrenme-öğretme süreçlerini tasarlayabilirim. & 3,63 & 0,83 \\
25.Hedefe uygun içerik yazabilirim. & 3,64 & 0,88 \\
26.Seçtiğim öğretim yöntemine uygun öğrenme-öğretme süreçlerini tasarlayabilirim. & 3,78 & 2,91 \\
27.İ̧eriği konu alanının hedefine göre tasarlayabilirim. & 3,60 & 0,84 \\
28.Derse/konu alanına ilişkin uygun yatay hedefler yazabilirim. & 3,36 & 0,81 \\
29. İçeriği hedefe uygun olarak zenginleştirebilirim. & 3,85 & 0,88 \\
\hline
\end{tabular}


Tablo 4'de bütün maddeler için alınan ortalama puanlar görülmektedir. En düşük ortalama puana sahip üç maddenin 28., 19. ve 17. maddeler olduğu görülmektedir. $\mathrm{Bu}$ maddeler yazma boyutuna aittir ve yatay hedef yazma, değerlendirme ölçütü yazma ve ölçme aracı hazırlama gibi öğretmenlerin eğitim programı ile ilişkili olarak eyleme geçtiği yeterlikler içermektedir. En yüksek ortalama puana sahip üç madde ise 8., 3. ve 2. maddelerdir. Bu maddeler de okuma boyutuna aittir ve hedef davranışın istediğini anlama, hedefe uygun içerik seçme ve içeriğin öğrenci seviyesine uygunluğu gibi daha çok var olan eğitim programını anlamaya yönelik yeterlikler içermektedir.

\subsection{Eğitim Programı Okuryazarlığı Düzeylerinin Cinsiyete Göre Farklılaşma Durumu}

İkinci araştırma sorusu kapsamında öğretmen adaylarının eğitim programı okuryazarlığı düzeylerinin cinsiyete göre farklılaşıp farklılaşmadığını belirlemek için bağımsız örneklem t-testi gerçekleştirilmiştir. Analizin sonuçları Tablo 5’te verilmiştir.

Tablo 5: Eğitim programı okuryazarlığı düzeylerinin cinsiyete göre değişimi

\begin{tabular}{cccccccc}
\hline Boyut & Cinsiyet & $\mathrm{N}$ & $\overline{\mathrm{X}}$ & $\mathrm{ss}$ & $\mathrm{sd}$ & $\mathrm{t}$ & $\mathrm{p}$ \\
\hline \multirow{2}{*}{ Okuma } & Kadın & 151 & 3,82 & 0,55 & 208 & \multirow{2}{*}{0,696} & \multirow{2}{*}{0,487} \\
& Erkek & 59 & 3,76 & 0,54 & & & \\
\multirow{3}{*}{ Yazma } & Kadın & 151 & 3,69 & 0,62 & & \multirow{2}{*}{1,981} & $0,049^{*}$ \\
& Erkek & 59 & 3,50 & 0,60 & & & \\
\multirow{2}{*}{ Toplam } & Kadın & 151 & 3,75 & 0,54 & & 1,457 & 0,146 \\
& Erkek & 59 & 3,63 & 0,53 & & \\
\hline
\end{tabular}

${ }^{*} \mathrm{p}<0.05$

Tablo 5'te görüldüğü üzere, öğretmen adaylarının eğitim programı okuryazarlığ1 düzeyleri cinsiyete göre anlamlı bir farkl1lık göstermemektedir, $t(208)=1,457, p>0,05$. Boyutlara göre bakıldığında; okuma boyutunda da cinsiyete göre anlamlı bir farklılaşma bulunamamıştır. Yazma boyutunda ise anlamlı bir farklılık belirlenmiştir, $t(208)=1,981$, $\mathrm{p}<0,05$. Kadınların yazma boyutunda erkeklerden daha başarılı oldukları görülmektedir.

\subsection{Eğitim Programı Okuryazarlığı Düzeylerinin Öğrenim Türüne Göre Farklılaşma Durumu}

Öğretmen adaylarının eğitim programı okuryazarlığı düzeylerinin öğrenim türü değişkenine göre farklılaşma durumunu içeren üçüncü araştırma sorusu kapsamında gerçekleştirilen bağımsız örneklem t-testinin sonuçları Tablo 6'da sunulmuştur.

Öğretmen adaylarının eğitim programı okuryazarlığı düzeyleri öğrenim türüne göre ölçek toplamında anlamlı bir farkl1lı göstermemektedir, $t(208)=1,764, p>0,05$. Boyutlara göre ise; okuma boyutunda öğrenim türüne göre anlamlı bir farklılaşma yokken; yazma boyutunda anlamlı bir farkl11ı bulunmuştur, $\mathrm{t}(208)=2,172, \mathrm{p}<0,05$. Öğretmenlik programı öğrencilerinin yazma boyutunda formasyon programındaki öğrencilere göre daha başarılı oldukları görülmektedir. 
Tablo 6: Eğitim programı okuryazarlığı düzeylerinin öğrenim türüne göre değişimi

\begin{tabular}{cccccccc}
\hline Boyut & Öğrenim Türü & $\mathrm{N}$ & $\overline{\mathrm{X}}$ & $\mathrm{ss}$ & $\mathrm{sd}$ & $\mathrm{t}$ & $\mathrm{p}$ \\
\hline \multirow{2}{*}{ Okuma } & Öğretmenlik P. & 92 & 3,85 & 0,59 & 208 & \multirow{2}{*}{1,085} & 0,279 \\
& Formasyon P. & 118 & 3,77 & 0,50 & & & \\
\multirow{2}{*}{ Yazma } & Öğretmenlik P. & 92 & 3,74 & 0,72 & & 2,172 & $0,031^{*}$ \\
& Formasyon P. & 118 & 3,55 & 0,52 & & & \\
\multirow{2}{*}{ Toplam } & Öğretmenlik P. & 92 & 3,80 & 0,62 & & 1,764 & 0,080 \\
& Formasyon P. & 118 & 3,67 & 0,47 & & & \\
\hline
\end{tabular}

* $\mathrm{p}<0,05$

\subsection{Eğitim Programı Okuryazarlığı Düzeylerinin Yaşa Göre Farklılaşma Durumu}

Öğretmen adaylarının eğitim programı okuryazarlığı düzeylerinin yaş değişkenine göre anlamlı düzeyde farklılaşma durumunu içeren dördüncü araştırma sorusu ile ilişkili olarak öğretmen adaylarının yaşa göre puan ortalamaları Tablo 7'de sunulmuştur.

Tablo 7: Öğretmen adaylarının yaşa göre puan ortalamaları

\begin{tabular}{ccccc}
\hline Boyut & Yaş & $\mathrm{N}$ & $\overline{\mathrm{X}}$ & ss \\
\hline \multirow{5}{*}{ Okuma } & 20 & 12 & 3,67 & 0,54 \\
& 21 & 78 & 3,74 & 0,46 \\
& 22 & 56 & 3,81 & 0,54 \\
& 23 ve üstü & 64 & 3,90 & 0,62 \\
& Toplam & 210 & 3,81 & 0,54 \\
\hline \multirow{5}{*}{ Yazma } & 20 & 12 & 3,49 & 0,59 \\
& 21 & 78 & 3,60 & 0,63 \\
& 22 & 56 & 3,63 & 0,52 \\
& 23 ve üstü & 64 & 3,71 & 0,71 \\
Toplam & Toplam & 210 & 3,63 & 0,62 \\
& 20 & 12 & 3,58 & 0,50 \\
& 21 & 78 & 3,67 & 0,50 \\
& 22 & 56 & 3,73 & 0,50 \\
& 23 ve üstü & 64 & 3,81 & 0,63 \\
& Toplam & 210 & 3,72 & 0,54 \\
\hline
\end{tabular}

Tablo 7'de görüldüğü üzere, öğretmen adaylarının ölçeğin iki faktöründe ve toplamında almış oldukları ortalama puanlar yaşa göre artmaktadır. Bu farklılığın anlamlılık düzeyini test etmek için gerçekleştirilen tek yönlü ANOVA analizi sonuçları Tablo 8'de yer almaktadır.

Tablo 8: Eğitim programı okuryazarlığı düzeylerinin yaşa göre değişimi

\begin{tabular}{cccccc}
\hline Varyansın Kaynağı & Kareler Toplamı & $\mathrm{sd}$ & $\begin{array}{c}\text { Kareler } \\
\text { Ortalaması }\end{array}$ & $\mathrm{F}$ & $\mathrm{p}$ \\
\hline Gruplar arası & 0,886 & 3 & 0,295 & 0,993 & 0,397 \\
Gruplar içi & 61,233 & 206 & 0,297 & & \\
Toplam & 62,119 & 209 & & & \\
\hline
\end{tabular}

Öğretmen adaylarının yaşları ile eğitim programı okuryazarlığı düzeyleri arasında anlamlı bir farklılık bulunamamıştır, $F(3,206)=0,993, p>0,05$. Öğretmen adaylarının yaşlarının eğitim program okuryazarlığı düzeyleri üzerinde anlamlı bir değişken olmadığ ifade edilebilir. 


\subsection{Eğitim Programı Okuryazarlığı Düzeylerinin Bölüme Göre Farklılaşma Durumu}

Öğretmen adaylarının eğitim programı okuryazarlığı düzeylerinin bölüm değişkenine göre anlamlı düzeyde farklılaşma durumunu içeren beşinci araştırma sorusu ile ilişkili olarak öğretmen adaylarının bölümlere göre puan ortalamaları Tablo 9'da sunulmuştur.

Tablo 9: Öğretmen adaylarının bölümlere göre puan ortalamaları

\begin{tabular}{ccccc}
\hline & Bölüm & N & $\bar{X}$ & ss \\
\hline \multirow{4}{*}{ TOPLAM } & Türkçe Ö. & 35 & 3,92 & 0,64 \\
& Matematik Ö. & 31 & 3,59 & 0,56 \\
& Tarih & 31 & 3,76 & 0,53 \\
& Matematik & 28 & 3,49 & 0,36 \\
& Türk Dili ve Ed. & 39 & 3,69 & 0,45 \\
& Biyoloji & 20 & 3,70 & 0,48 \\
& Sosyal Bil. Ö. & 26 & 3,89 & 0,63 \\
\hline
\end{tabular}

En yüksek ortalama puana sahip bölümlerin Türkçe öğretmenliği ve sosyal bilgiler öğretmenliği, en düşük ortalama puana sahip bölümün ise Matematik bölümü (formasyon) olduğu görülmektedir. Matematik öğretmenliği bölümünün Tarih, Türk Dili ve Edebiyatı ve Biyoloji gibi formasyon programındaki bölümlerden daha düşük ortalama puana sahip olması dikkat çekicidir. Bölümler arası farklılık anlamlılığını test etmek için gerçekleştirilen tek yönlü ANOVA analizi sonuçları Tablo 10'da yer almaktadır.

Tablo 10: Eğitim programı okuryazarlığı düzeylerinin bölümlere göre değişimi

\begin{tabular}{cccccc}
\hline $\begin{array}{c}\text { Varyansın } \\
\text { Kaynağ } 1\end{array}$ & $\begin{array}{c}\text { Kareler } \\
\text { Toplamı }\end{array}$ & sd & Kareler Ortalaması & F & p \\
\hline Gruplar arası & 4,259 & 6 & 0,710 & 2,491 & $0,024^{*}$ \\
Gruplar içi & 57,285 & 203 & 0,285 & & \\
Toplam & 62,119 & 209 & & & \\
${ }^{*} \mathrm{p}<0,05$ & & & & &
\end{tabular}

Öğretmen adaylarının bölümleri ile eğitim programı okuryazarlığı düzeyleri arasında anlamlı bir farklılık bulunmaktadır, $\mathrm{F}(6,203)=2,491, \mathrm{p}<0,05$. Bu anlamlı farklılığın hangi bölümler arasında olduğunu belirlemek için varyanslar homojen olduğundan $(p>0,05)$ Tukey HSD çoklu karşılaştırma analizi yapılmıştır. Bu analizin sonuçlarına göre, Türkçe öğretmenliği bölümü $(X=3,92)$ ile Matematik (formasyon) bölümü $(X=3,49)$ arasındaki farkın anlamlı olduğu belirlenmiştir $(\mathrm{p}=0,027)(\mathrm{p}<0,05)$.

Boyutlara göre bakıldığında ise, okuma boyutunda anlamlı bir farklılık olmadığı ( $>>0,05)$; yazma boyutunda ise anlamlı bir farklılığın olduğu belirlenmiştir $(F(6,203)=2,8$, $\mathrm{p}<0,05)$. Yazma boyutuna ilişkin yapılan tek yönlü ANOVA testinin sonuçları Tablo 11'de sunulmuştur.

Tablo 11'de görülen bu anlamlı farklılı̆̆ın hangi bölümler arasında olduğunu belirlemek için varyanslar homojen olduğundan $(p>0,05)$ Tukey HSD çoklu karşılaştırma analizi yapılmıştır. Bu analizin sonuçlarına göre ise farklılığın Türkçe öğretmenliği bölümü 
$(\mathrm{X}=3,90)$ ile Matematik (formasyon) bölümü $(\mathrm{X}=3,37)$ arasında olduğu belirlenmiştir $(\mathrm{p}=0,013)$.

Tablo 11: Yazma boyutu ortalamalarının bölümlere göre değişimi

\begin{tabular}{cccccc}
\hline Varyansın & Kareler & sd & Kareler & F & p \\
Kaynağı & Toplamı & Ortalaması & 2,800 & $0,012^{*}$ \\
\hline Gruplar arası & 6,295 & 6 & 1,049 & & \\
Gruplar içi & 76,058 & 203 & 0,375 & & \\
Toplam & 82,354 & 209 & & & \\
\hline
\end{tabular}

${ }^{*} \mathrm{p}<0,05$

\section{6. Ĕ̆itim Programı Okuryazarlığı Düzeylerinin Akademik Başarıya Göre Farklılaşma Durumu}

Öğretmen adaylarının eğitim programı okuryazarlığı düzeylerinin akademik başarı değişkenine göre anlamlı düzeyde farklılaşma durumunu içeren altıncı araştırma sorusu ile ilişkili olarak öğretmen adaylarının bölümlere göre puan ortalamaları Tablo 12'de sunulmuştur.

Tablo12: Öğretmen adaylarının akademik başarıya göre puan ortalamaları

\begin{tabular}{ccccc}
\hline & Bölüm & $\mathrm{N}$ & $\overline{\mathrm{X}}$ & ss \\
\hline \multirow{4}{*}{ TOPLAM } & Şartlı geçer (1.5-1.99) & 12 & 3,54 & 0,36 \\
& Geçer (2.00-2.49) & 34 & 3,70 & 0,47 \\
& Orta (2.50-2.99) & 103 & 3,64 & 0,54 \\
& İyi (3.00-3.49) & 57 & 3,91 & 0,57 \\
& Pekiyi (3.50-3.99) & 4 & 3,90 & 0,57 \\
\hline
\end{tabular}

Tablo 12 incelendiğinde, 'orta' düzey akademik başarı haricinde öğretmen adaylarının eğitim programı okuryazarlığı düzeylerinin akademik başarı ile paralel olarak arttığ1 görülmektedir ancak 'orta' düzey akademik başarı bir önceki düzey olan 'geçer'in gerisinde kalmıştır. Akademik başarıya göre farklılığın anlamlılı̆̆ını test etmek için gerçekleştirilen tek yönlü ANOVA analizi sonuçları Tablo 13'te yer almaktadır.

Tablo 13: Eğitim programı okuryazarlığı düzeylerinin akademik başarıya göre değişimi

\begin{tabular}{cccccc}
\hline Varyansın & Kareler Toplamı & sd & Kareler & Ortalamas & p \\
Kaynağ 1 & 3,018 & 4 & 0,755 & 2,618 & $0,036^{*}$ \\
\hline Gruplar arası & 59,100 & 205 & 0,288 & & \\
Gruplar içi & 62,119 & 209 & & & \\
Toplam & & & & &
\end{tabular}

Öğretmen adaylarının eğitim programı okuryazarlığı düzeyleri akademik başarıları açısından anlamlı şekilde farklılaşmaktadır, $\mathrm{F}(4,205)=2,618, \mathrm{p}<0,05$. Bu anlamlı farklılığın hangi başarı grupları arasında olduğunu belirlemek için varyanslar homojen olduğundan (p>0,05) Tukey HSD çoklu karşılaştırma analizi yapılmıştır. Bu analizin sonuçlarına göre, orta yüzeyde akademik başarıya sahip öğrenciler $(X=3,64)$ ile iyi düzeyde akademik başarıya sahip öğrenciler $(X=3,91)$ arasındaki farkın anlamlı olduğu belirlenmiştir $(p=0,032)$ $(\mathrm{p}<0,05)$. 
Boyutlara göre ise, okuma boyutunda anlamlı bir farklılık olmadığ $1(p>0,05)$; yazma boyutunda ise anlamlı bir farklılığın olduğu belirlenmiştir $(F(4,205)=2,579, p<0,05)$. Yazma boyutuna ilişkin yapılan tek yönlü ANOVA testinin sonuçları Tablo 14'te sunulmuştur.

Tablo 14: Yazma boyutu ortalamalarının akademik başarıya göre değişimi

\begin{tabular}{cccccc}
\hline Varyansın Kaynağı & Kareler Toplamı & sd & Kareler Ortalaması & F & p \\
\hline Gruplar arası & 3,946 & 4 & 0,986 & 2,579 & $0,039^{*}$ \\
Gruplar içi & 78,408 & 205 & 0,82 & & \\
Toplam & 82,354 & 209 & & & \\
\hline
\end{tabular}

${ }^{*} \mathrm{p}<0,05$

Tukey HSD sonuçlarına göre ise yazma boyutunda anlamlı farklılı̆̆ın orta düzey $(X=3,54)$ ile iyi düzey $(X=3,85)$ arasında olduğu belirlenmiştir $(p=0,024)$.

\section{Tartışma ve Sonuç}

Çalışmanın ilk probleminde öğretmen adaylarının eğitim programı okuryazarlığı düzeylerinin «oldukça katılıyorum» $(3,72)$ düzeyinde olduğu belirlenmiştir. Bu durum öğretmenlik mesleğini yürütürken eğitim programlarının kullanıcısı durumunda olan öğretmen adayları için olumlu bir durumdur. Eğitim programı, eğitimin istendik ve planlı olma yönünü niteleyen önemli unsurlardan biridir ve bir ülkede eğitimin yönünü belirleyen bir rehber özelliği taşımaktadır. Çünkü politika yapıcılar bir ülkede yetiştirmek istedikleri insan gücüne dair özellikleri eğitim programına yansıtmakta ve bu yapı aracılığıyla hedeflere ulaşmayı amaçlamaktadırlar (Oliva, 2009). Bu nedenle öğretmen adaylarının programa dair okuryazarlık boyutunda kendilerini yeterli görmeleri önemli bir durumdur. Süral ve Dedebali (2018) de yaptıkları çalışmada program okuryazarlığı ölçeğinden elde edilen ortalamayı 3,99 olarak tespit etmişlerdir. Bu durum çalışmamızın bulgularıyla uyuşmaktadır.

$\mathrm{Bu}$ sonuçlar yorumlanırken araştırmada kullanılan ölçeğin bir öz değerlendirme ölçeği olduğu unutulmamalıdır. Öğrencilerin kendi becerilerine verdiği puanlar ile gerçek performansları arasında orta veya düşük düzeyde bir ilişki vardır. Öğrenciler kendi becerilerine dönük yaptıkları değerlendirmelerde kendilerine yüksek puan verme eğilimindedirler (Dunning, Heath ve Suls, 2004). Bu noktada Sağ ve Sezer (2012) öğretmenler üzerine yaptıkları çalışmada kıdem arttıkça öğretmenlerin program okuryazarlığına ilişkin beceri gelişimine daha çok ihtiyaç duyduğunu belirlemiştir. Buna dayalı olarak öğretmen adaylarının mesleği aktif olarak yapmaya başlayana kadar ihtiyaçlarının ve buna bağlı olarak gerçek düzeylerinin farkına varamadığı ifade edilebilir. Özellikle düşük puan alınan maddeler kritik eksikliklere işaret etmekle birlikte, bu ölçek aracılığıyla elde edilen sonuçları desteklemek için öğretmen adaylarının bu konuda gerçek yeterliğini ortaya koyacak performans göstergelerine ve konu hakkında derinlemesine görüş sağlayacak nitel verilere ihtiyaç vardır.

Çalışmanın bulgularına göre öğretmen adaylarının yazma boyutunda okuma boyutuna göre daha başarısız oldukları görülmektedir. Öğretmen adayları var olan eğitim programlarını daha rahat anlayabilmekte iken eğitim materyali tasarlama, ölçme aracı hazırlama, etkinlik tasarlama, hedef yazma, içeriği zenginleştirme gibi kendilerinin eyleme geçtiği durumlarda eksiklikler yaşamaktadırlar. Bu durum öğretmenlik sürecinde çeşitli 
eksikliklere neden olacaktır. Sağ ve Sezer (2012) de yaptıkları çalışmada örneklemi oluşturan öğretmenlerin \%55-65'inin program okuryazarlığına ilişkin beceri gelişimine ihtiyaç duyduğunu belirlemiştir. Karakuş (2016) ise öğretmen adaylarının program okuryazarlığı becerilerine yönelik orta düzeyde bir algıya sahip olduklarını belirlemiştir.

Eğitim materyali tasarlama, ölçme aracı hazırlama, eğitsel etkinlikler tasarlama, hedef yazma, yöntem ve tekniğe uygun öğrenme-öğretme süreçleri tasarlama gibi beceriler "yazma" boyutu altında karşımıza çıkmaktadır. Yazma boyutunda genellikle eğitim programının ögelerine dönük bağlama uyarlanmış özgün ürünler oluşturmak vurgulanmaktadır. Yani yazma boyutunda öğretmen adayları eğitim programının hedef, içerik, öğretim yöntem ve teknikleri ile ölçme değerlendirme araçlarını kendi bağlamlarına uygun bir şekilde diğer ögeleri de göz önüne alarak tasarlayacaklardır. Diğer boyut olan "okuma" boyutunda ise eğitim programı ögelerine ilişkin yorumlama, değerlendirme ve anlamlandırma becerileri öncelenmektedir. Bu haliyle yazma boyutundaki becerilerin okuma boyutundaki becerilerden daha üst düzey olduğu söylenebilir. $\mathrm{Bu}$ nedenle, öğretmen adaylarının eğitim programlarını kendi içerisinde bulundukları durumlara göre uyarlayarak ihtiyaç duyulan özgün ürünleri geliştirme konusunda gelişime ihtiyaç duymaktadırlar.

$\mathrm{Bu}$ çalışmada da öğretmen adayları branşlarına dair programı mevcut haliyle yorumlama ve anlamlandırmaya dönük yeterliliklerini, ögeleri bağlama göre yeniden tasarlamaya göre daha yüksek algılamaktadırlar. Bu nedenle öğretmen adaylarının aldıkları teorik ve uygulamalı eğitimin onların programa dair özgün ürünler oluşturabilme yetilerini desteklemekte yeteri kadar başarılı olmadığı yorumu yapılabilir. Küçüktepe (2013) de sınıf içi öğretmen ihtiyaçlarını belirlediği çalışmada, program okuryazarlığına dair becerilere duyulan ihtiyacın sekiz başlık içerisinde ikinci sırada olduğunu ifade etmiştir. Öğretmenler en çok kazanımların taksomonik özelliklerini belirleme, yapılandırmacılık ilkelerini uygulama, test geliştirme veya alternatif ölçme aracı tasarlama, bilgisayarda materyal hazırlama, yeni yaklaşımlara, düşünme becerilerine veya aktif öğrenmeye dönük etkinlik oluşturma gibi becerilerde eksik olduklarını söylemiş̧ir. Bu bulgunun öğretmen adaylarının genelde yazma boyutu altında kendileri tarafindan bir öge tasarlanması ihtiyac1 duyduklarının ifade edildiği bu çalışmayla paralellik gösterdiği ifade edilebilir.

$\mathrm{Bu}$ durumu öğretmen eğitiminin problemlerinden biri olan mesleki uygulamaların süreçteki ağırlığının az olması faktörü ortaya çıkarmış olabilir. Yani programda belirlediği herhangi bir kazanıma dönük birkaç saatlik ders tasarlama becerisini sergileme imkânı bulamayan öğrenciler haliyle bu yetilerini de geliştirememekte ve de teorik ağırlığa paralel olarak sadece programın mevcut teorik hali üzerinde yorumlamalar yapabilmektedir. Sağ (2010) yaptığı çalışmada öğretmen adaylarının doğrudan yaşantıya dayalı etkinliklerle zenginleştirilen programla aldıkları eğitim sonucunda program okuryazarlığına ilişkin özgüvenlerinin kontrol grubuna göre anlamlı şekilde arttığını belirlemiştir. Yine Karakuş (2016) öğretmen adaylarına çalışacakları ortamla ilgili gezi-gözlem etkinliklerine katılmalarının program okuryazarlığı özyeterlik algılarını anlamlı biçimde arttırdığını belirlemiştir. Bu bulgu öğretmen adaylarının ileride çalışacakları ortama ilişkin ön keşifler yapmalarının ve yaşantılar geçirmelerinin program okuryazarlığı algısına olumlu etkisini destekleyen bir durumu betimlemektedir. Bu durum program okuryazarlığına özellikle de yazma boyutuna ilişkin becerilerin uygulama ile gelişebileceği görüşünü desteklemektedir. 
Ölçeğin genelinde cinsiyete göre anlamlı bir fark çıkmamıştır ancak yazma boyutunda kadınların daha başarılı oldukları görülmüştür. Sağ ve Sezer (2012) ve Karakuş (2016) yaptıkları çalışmada öğretmenlerin program okuryazarlığına ilişkin beceri gelişimine ihtiyaçlarının cinsiyet değişkenine göre değişmediğini belirlemiştir. Karakuş (2016) ayrıca kadın öğretmen adaylarının program okuryazarlığı özyeterlik algılarının erkek adaylardan daha yüksek olduğunu tespit etmiştir. Bu çalışmayla paralellik gösteren bu bulgunun öğretmenlik mesleğinin cinsiyet değişkenine bağlı olmadan gerçekleştirilebilen bir meslek olması ve bu mesleği yaparken geleneksel cinsiyet rollerinin mesleğe ilişkin süreçlerde belirgin rol oynamaması gösterilebilir (Karakuş ve Tümkaya, 2015; Tümkaya, Bal ve Karaçoban, 2014).

Ölçeğin genelinde öğretmenlik programı öğrencileri ile formasyon öğrencileri arasında anlamlı bir fark bulunamamıştır. Sadece yazma boyutunda öğretmenlik programı öğrencilerinin daha başarılı oldukları görülmüştür. Bu oldukça düşündürücü bir bulgudur. Çünkü uzun bir sürece yayılmış öğretmenlik eğitimi ile kısa bir süreçte tamamlanan pedagojik formasyon eğitiminin ölçeğin tamamında yeterlilik düzeyleri arasında bir farklılaşma oluşturmadığına dair bulgu özellikle öğretmenlik eğitiminin niteliğini sorgulatacak bir durumdur. Buna karşın program okuryazarlığına dair daha üst düzey becerilere atıf yapan yazma boyutunun eğitim fakültesi mezunlarında daha yüksek çıkması özgün ürünler oluşturmak noktasında daha çok firsatla karşılaşan eğitim fakültesi öğrencileri için beklenen bir bulgudur. Öğretmenlik eğitimi mezunları ile pedagojik formasyon mezunlarının öğretmenlik formasyonu açısından hemen hemen aynı dersleri almalarına rağmen öğretmenlik eğitimi öğrencileri sürece yayılmış, başarı ölçütleri daha yüksek, önbilgileri daha kapsamlı, becerilerini gösterme firsatına daha çok sahip olduklarından yazma boyutundaki becerilerin de daha çok gelişmesi mümkün olmaktadır.

Öğretmen adaylarının eğitim programları okuryazarlığı düzeylerinde yaş anlamlı bir değişken değildir. Süral ve Dedebali (2018), 3. ve 4. sınıf eğitim fakültesi öğrencileri üzerine yaptıkları çalışmada sınıf düzeyinin program okuryazarlığ 1 ve her iki alt boyutu için de 4 . sınıflar lehine anlamlı farklılık oluşturduğunu belirlemiştir. Bu çalışmada ise yalnızca son sınıf öğrencileri üzerine çalışılmış ve öğrencilerin yaşı bir değişken olarak alınmıştır. Çalışmada yaş anlamlı bir değişken değildir fakat yaş arttıkça ölçekten elde edilen puanlar artmaktadır.

Bölüm açısından bakıldığında, sadece Türkçe öğretmenliği ile Matematik (formasyon) bölümü arasındaki farkın anlamlı olduğu belirlenmiştir. Öğretmenlik programı öğrencilerinin formasyon programı öğrencilerinden daha başarılı bulunmaları beklentisi karşılık bulmamıştır. Akademik başarı açısından, orta düzey ile iyi düzey grupları arasında iyi düzey lehine anlamlı bir farklılık bulunmuştur. Ortalamalara bakıldığında, orta düzey haricinde başarı arttıkça okuryazarlık düzeyinin arttığı görülmüştür. Bu durumdan hareketle öğretmen adaylarının öğretmenlik formasyonu ders içeriklerinin bu yetileri geliştirmeye dönük hazırlandığı sonucuna varılabilir.

Öğretmen adaylarının eğitim programı okuryazarlığı düzeylerini belirlemeyi amaçlayan bu araştırma, öğretmen adaylarının meslek sürecinde en çok ihtiyaç duyacakları alanlardan biri olan eğitim programı okuryazarlığının araştırma gündemine alınması bakımından önem taşımaktadır. Eğitim programı okuryazarlığı kavramı öğretmenlerin ve öğretmen adaylarının bu konuda yetkinliklerini ölçülebilir hale getirdiği için üzerinde 
önemle durulması gereken bir kavramdır. Bu araştırmada kullanılan ölçek geliştirilerek daha kapsayıcı hale getirilebilir. Benzer çalışmalar farklı öğretmen adayları üzerinde gerçekleştirilerek öğretmen yetiştirme programlarının bu anlamda değerlendirilmesi mümkün kılınabilir ve öğretmen yetiştiren programlara eksiklik alanları konusunda dönüt sağlanmış olur. Özellikle öğretmen adaylarının yazma boyutunda daha başarısız olmalarından hareketle öğretmen yetiştirme programlarında eğitim programının yazma boyutuna ilişkin yeterliklere daha fazla ağırlık verilmelidir. Ayrıca öğretmenler ile yapılacak uygulamalar da bu konuda düzenlenecek hizmet içi eğitim programları için ihtiyaç analizi çalışması olarak işlev görebilir. Ancak bu tür çalışmaların nitel veriler ile desteklenmesi daha geçerli sonuçlara ulaşmak açısından önemli görülmektedir.

\section{Kaynakça}

Akınoğlu, O. ve Doğan, S. (2012). Eğitimde Program Geliştirme Alanına Yeni bir Kavram Önerisi: Program Okuryazarlığı. 21. Ulusal Eğitim Bilimleri Kongresi, 12-14 Eylül 2012, Marmara Üniversitesi, İstanbul.

Bawden, D. (2001). "Information and Digital literacies: A review of concepts", Journal Documentation, 57(2): 218-259.

Bolat, Y. (2017). "Eğitim Programı Okuryazarlığı Kavramı ve Eğitim Programı Okuryazarlığı Ölçeği”, International Periodical for the Languages, Literature and History of Turkish or Turkic, 12(18): 121-138.

Creswell, J. W. (2014). Research Design: Qualitative, Quantitative and Mixed Methods Approaches, Los Angeles: Sage Publications.

Cunningham, J. W. (2000). "How Will Literacy be Defined in the New Millenium?", Reading Research Quarterly, 35(1): 64-71.

Demeuse, M. ve Strauven, C. (2016). Eğitimde Program Gelişstirme: Politik Kararlardan Uygulamaya (Çev: Y. Budak), Ankara: Pegem Akademi.

Demirel, Ö. (2017). Eğitimde Program Geliştirme: Kuramdan Uygulamaya, Ankara: Pegem Akademi.

Dunning, D., Heath, C. ve Suls, M. (2004). "Flawed Self-assessment: Implications for Health, Education and Workplace", Psychol Sci Public Interest, 5(3): 69-106.

Erdem, C. (2018). Medya Okuryazarlığı ve Öğretmen Ĕgitimi: Öğretmen Adayları için bir Öğretim Programı Tasarısı, Ankara: Pegem Akademi.

Erişti, B. ve Erdem, C. (2017). "Development of a Media Literacy Skills Scale", Contemporary Educational Technology, 8(3): 249-267.

Goodfellow, R. (2011). "Literacy, Literacies and the Digital in Higher Education", Teaching in Higher Education, 16(1): 131-144.

Karakuş, F. (2016). "Öğretmen Adaylarının Birleştirilmiş Sınıf Öğretmeni Olmaya Yönelik Yeterlik Algiları”, Turkish Studies, 11(19), 491-510.

Karakuş F. ve Tümkaya S. (2015). "Sınıf Öğretmenlerinin Empatik Beceri Düzeylerinin Sosyodemografik Değişkenlere ve Tercih Ettikleri Disiplin Türlerine göre İncelenmesi”, Pegem Ĕ̈itim ve Öğretim Dergisi, 5: 375-396.

Kellner, D. ve Share, J. (2005). "Toward Critical Media Literacy: Core Concepts, Debates, Organizations and Policy”, Discourse: Studies in the Cultural Politics of Education, 26 (3): 369-386.

Keskin, A. \& Korkmaz, H. (2017). Öğretmenlerin "Program Okuryazarlığı” Kavramına Yükledikleri Anlam. 5. Uluslararası Eğitim Programları ve Öğretim Kongresi. 26-28 Ekim 2017, Muğla, Türkiye. 
Kress, G. (2003). Literacy in the New Media Age, Londra: Routledge.

Kurbanoğlu, S. S. (2010). "Bilgi Okuryazarllğı: Kavramsal bir Analiz", Türk Kütüphaneciliği, 24(4): 723-747.

Küçüktepe, C. (2013). "Sınıf Öğretmenlerinin Hizmet İçi Eğitim İhtiyaçlarının Öğretmen Görüşlerine göre Belirlenmesi”, Abant İzzet Baysal Üniversitesi Eğitim Fakültesi Dergisi, 13(2): 26-43.

Lankshear, C. J., ve Knobel, M. (2008) "Introduction: Digital Literacies: Concepts, Policies and Practices", İçinde: Digital Literacies: Concepts, Policies and Practices (Ed: C. Lankshear ve M. Knobel), New York: Peter Lang Publishing.

Livingstone, S. (2003). "The Changing Nature and Uses of Media Literacy". MEDIA@LSE Electronic Working Papers, 4.

Livingstone, S. (2014). "Developing Social Media Literacy: How Children Learn to Interpret Risky Opportunities on Social Network Sites", Communications, 39(3): 283-303.

Nsibande, R. N. ve Modiba, M. M. (2012) “'I Just Do As Expected'. Teachers' implementation of Continuous Assessment and Challenges to Curriculum Literacy", Research Papers in Education, 27(5): 629-645

OECD. (2006). Assessing Scientific, Reading and Mathematical Literacy. A Framework for PISA 2006, Paris: OECD Publishing.

Oliva, P. F. (2009). Developing the Curriculum, Boston: Ally and Bacon.

Ornstein, A. C. ve Hunkins, F. P. (2017). Curriculum: Foundations, Principles and Issues, Vivar: Pearson Education.

Pegrum, M. (2010). “'I Link, Therefore I am': Network Literacy As a Core Digital Literacy", E-Learning and Digital Media, 7(4): 346-354.

Sağ, R. (2010). "Etkinlik Teorisine Göre Zenginleştirilmiş Birleştirilmiş Sınıflarda Öğretim Uygulamalarının Adayların Özyeterlik Algılarına Etkisi”, Eğitim ve Bilim, 35(158): 4457.

Sağ, R. ve Sezer, R. (2012). "Birleştirilmiş Sınıf Öğretmenlerinin Mesleki Eğitim İhtiyaçları", Illkögretim Online, 11(2): 491-503.

Süral, S. ve Dedebali, N. C. (2018). "Study of Curriculum Literacy and Information Literacy Levels of Teacher Candidates in Department of Social Sciences Education", European Journal of Educational Research, 7(2): 303-317.

Som, S. ve Kurt, A. A. (2012). "Bilgisayar ve Öğretim Teknolojileri Eğitimi Bölümü Öğrencilerinin Medya Okuryazarlık Düzeyleri”, Anadolu Journal of Educational Sciences International, 2(1): 104-119.

Street, B. (2003). "Autonomous and Ideological Models of Literacy: Approaches from New Literacy Studies", Current Issues in Comparative Education, 5(2): 1-15.

Şahin, M. ve Barış, S. (2017). "Finansal Okuryazarlık ve Tasarruf Davranşları: Kamu Çalışanları Üzerine bir İnceleme", Çankırı Karatekin Üniversitesi İktisadi ve İdari Bilimler Fakültesi, 7(2): 77-103.

Tavşancıl, E. (2006). Tutumların Ölçülmesi ve SPSS ile Veri Analizi, Ankara: Nobel.

Tümkaya S., Bal L. ve Karaçoban F. (2014). "Öğretmen Adaylarının Eğitme-Öğretme Özyetkinlik Düzeylerinin Bazı Değişkenler Açısından İncelenmesi”, İlköğretim Online, 13(2): 412-424.

Tyler, R. (1949). Basic Principles of Curriculum and Instruction. Chicago: University of Chicago.

Wiles, J. (2016). Ĕgitim Program Liderliği (Çev. Ed.: M.B. Acat), Ankara: Nobel.

Yanılmaz, M. (2011). Hukuk Okuryazarlı̆̆l, Ankara: Aile ve Sosyal Politikalar Bakanlığı. 